\title{
PENERAPAN ALGORITME FP-GROWTH UNTUK MENENTUKAN PELETAKAN BARANG PEDAGANG SAYUR
}

\author{
Wahyu Alfafisabil ${ }^{1}$, Budi Arif Dermawan ${ }^{2}$, Tesa Nur Padilah ${ }^{3}$ \\ Teknik Informatika, Ilmu Komputer, Universitas Singaperbangsa Karawang \\ wahyu.16222@student.unsika.ac.id ${ }^{1}$, budi.arif@staff.unsika.ac.id², tesa.nurpadilah@staff.unsika.ac.id ${ }^{3}$
}

\begin{abstract}
Abstrak
Sayuran merupakan sumber vitamin dan protein. Setiap ibu rumah tangga membutuhkan sayuran untuk memasak dalam kehidupan sehari-hari. Sayuran didapatkan di pasar sehingga akan mempersulit ibu rumah tangga yang rumahnya jauh dari pasar. Pedagang sayur keliling merupakan pedagang yang menjual berbagai macam sayuran yang dibawa ke rumah-rumah untuk memenuhi kebutuhan ibu rumah tangga. Pedagang sayur keliling bertujuan untuk mencari keuntungan, sehingga untuk memaksimalkan tingkat penjualan diperlukan strategi penjualan. Association rules adalah metode untuk mencari hubungan antar item pada suatu dataset. Data mining dapat disebut salah satu langkah dari proses KDD. FP-Growth merupakan algoritme untuk mencari himpunan data yang paling sering muncul. Penelitian ini menganalisis data transaksi untuk memprediksi peletakan barang dipedagang sayur dengan tujuan memaksimalkan tingkat penjualan menggunakan algoritme FP-Growth dan bahasa pemrograman python. Pada proses data mining dengan menggunakan algoritme FPGrowth peneliti menjelaskan langkah-langkah FP-Growth dengan perhitungan manual. Evaluasi peneliti melakukan pencocokan hasil perhitungan manual dengan program. Setelah perhitungan sesuai, peneliti menggunakan data tota transaksi untuk mengetahui rules-nya dengan syarat minimum support 0.01 atau $1 \%$ dan minimum confidence 0.9 atau $90 \%$. Pada hasil terdapat 44 rules yang memenuhi syarat.
\end{abstract}

Kata kunci : Aturan Asosiasi, FP-Growth, Data Mining.

\section{Pendahuluan}

Menurut Ramli (1992) yang dikutip oleh Lelawati (2015) saat ini sektor informal berkembang pesat di Indonesia. Hal ini karena sektor informal dapat memberi ruang kepada masyarakat yang tidak memiliki skill dalam sektor ekonomi formal. Salah satu sektor informal yaitu pedagang kecil.

Sayuran merupakan hal penting dalam kehidupan sehari-hari karena sebagai sumber vitamin dan protein. Setiap ibu rumah tangga membutuhkan sayuran untuk memasak. Sayuran dapat didapatkan di pasar, setiap ibu rumah tangga tidak selalu rumahnya berdekatan dengan pasar sehingga hal ini mempersulit ibu rumah tangga yang rumahnya jauh dari pasar. Hal ini dapat dimanfaatkan oleh pedagang kecil. Pedagang kecil merupakan pedagang yang membuka tempat berjualan sederhana atau pedagang keliling yang mendatangi konsumennya. Pedagang sayur keliling merupakan pedagang yang menjual berbagai macam sayuran yang dibawa ke rumah-rumah untuk memenuhi kebutuhan ibu rumah tangga (Sapari, 2016). Pedagang sayur keliling bertujuan untuk mencari keuntungan, untuk memaksimalkan tingkat penjualan sayuran tersebut diperlukan strategi penjualan. Menurut Utami (2004) yang dikutip oleh Khair (2016) banyaknya variasi barang, lokasi yang mudah dijangkau, pelayanan yang ramah dan membantu, kestabilan harga, harga murah, serta mudah menjangkau dan memilih barang dagangan merupakan beberapa faktor-faktor pendukung yang mempengaruhi keputusan pembeli.

Menurut Griffin yang dikutip oleh Hanum \& Hidayat (2017) perilaku konsumen merupakan semua kegiatan serta psikologi yang mendorong Tindakan pada saat sebelum membeli sampai menghabiskan produk dan jasa setelah kegiatan mengevaluasi.

Pentingnya penelitian ini dilakukan karena penulis menemukan pedagang sayur di daerah Cibarusah Indah yang kesulitan dalam hal menjual sayuran tersebut, salah satu faktornya yaitu sulit menjangkau dan memilih barang dagangan. Seperti pada saat ingin mengambil sesuatu kita perlu mencari terlebih dahulu atau bertanya kepada pedagang tersebut. Jika pembeli sedang banyak tidak selalu pedagang tersebut bisa memberi tahu kita sehingga pembeli tidak menemukan sayuran yang dicari. Pembeli akan menganggap sayuran tersebut tidak ada dan pergi tidak jadi membeli. Sehingga hal ini dapat mempengaruhi tingkat penjualan sayuran dari pedagang tersebut.

Penelitian Fajrin \& Maulana (2018) yang berjudul "Penerapan Data Mining untuk Analisis Pola Pembelian Konsumen dengan Algoritma FPGrowth Pada Data Transaksi Penjualan Spare Part Motor" penelitian tersebut menggunakan 150 data 
dan menghasilkan 12 rules dengan output sebuah aplikasi.

Pedagang sayur sebaiknya mencermati polapola pembelian konsumen pada setiap transaksi yang nantinya akan sangat berguna untuk peletakan sayuran. Pedagang sayur tidak memiliki data transaksi, sehingga pedagang sayur tersebut tidak dapat mencermati pola-pola pembelian konsumen. Dari masalah tersebut diperlukan strategi peletakan sayuran sesuai dengan perilaku konsumen yang dapat meningkatkan penjualan.

\section{Landasan Teori}

\subsection{Pedagang}

Dalam Kamus Besar Bahasa Indonesia (KBBI) pedagang merupakan "orang yang mencari nafkah dengan berdagang”. Dalam KBBI berdagang merupakan "berjual beli", sedangkan dalam KBBI dagang merupakan "pekerjaan yang berhubungan dengan menjual dan membeli barang untuk memperoleh keuntungan".

\subsection{Perilaku Konsumen}

Menurut Simamora (2004) yang dikutip oleh Saodah \& Malia (2017) perilaku konsumen dipengaruhi oleh faktor eksternal dan internal dalam diri manusia. Faktor eksternal yang utama yaitu faktor kebudayaan dan sosial, faktor internal yang utama yaitu faktor pribadi dan psikologis.

\subsection{Data Mining}

\section{a. Pengertian Data Mining}

Data mining adalah teknik untuk menggali informasi yang tersembunyi dari suatu data (Parhusip, 2019). Menurut pregibon dalam Parhusip (2019) "data mining adalah campuran dari statistik, keceradasan buatan dan riset basis data yang masih berkembang".

b. Tahap-tahap Data Mining

Pembersihan Data (Data Cleaning), Integrasi Data (Data Integration), Seleksi Data (Data Selection), Transformasi Data (Data Transformation), Proses Mining, Evaluasi (Evaluation).

\subsection{Analisis Asosiasi}

Analisis Asosiasi atau Association Rules merupakan metode untuk mencari hubungan antar item pada suatu dataset. Penerapan aturan asosiasi bertujuan untuk menemukan informasi pada itemitem yang saling berhubungan dalam bentuk aturan. Aturan asosiasi adalah aturan asosiasi antar suatu kombinasi item (Afdal \& Rosadi, 2019).

Support (nilai penunjang) merupakan persentase dari kombinasi item, sedangkan confidence (nilai kepastian) merupakan kuatnya hubungan antar item dalam aturan asosiasi (Sikumbang, 2018).

Persamaan support terdapat pada persamaan 1.

Support $(\mathrm{A})=\frac{\Sigma J \text { umlah transaksi yang mengandung } \mathrm{A}}{\Sigma \text { Total Transaksi }} \times 100 \%$

Persamaan support dari 2 item diperoleh menggunakan rumus terdapat pada persamaan 2 .

Support $(\mathrm{A}, \mathrm{B})=\frac{\Sigma \text { Jumlah transaksi yang mengandung A dan B }}{\Sigma \text { Total Transaksi }} \times 100 \%$
$\quad$ Persamaan $\quad$ confidence terdapat
persamaan 3.
Confidence $(\mathrm{A}, \mathrm{B})=\frac{\Sigma \text { Jumlah transaksi yang mengandung A dan } \mathrm{B}}{\Sigma \text { Transaksi mengandung A }} \times 100 \%$ (3)

\subsection{Knowledge Discovery in Database (KDD)}

Knowledge Discovery in Database (KDD) sering digunakan untuk proses penggalian informasi pada suatu database yang besar (Rahmawati \& Merlina, 2018).

FP-Growth merupakan algoritme yang efektif untuk mencari himpunan data yang paling sering muncul (frequent itemset), algoritme ini dapat menemukan frequent itemset hanya dengan sedikit mengakses pada database asli dan pendekatan algoritme ini paling efisien (Junaidi, 2019). Dalam pencarian frequent itemset FP-Growth menggunakan konsep pembangunan tree sehingga FP-Growth lebih cepat dibandingkan algoritme apriori (Sholikin, 2019). Metode FP-Growth memiliki tiga tahap utama yaitu:

a. Pembangkitan conditional pattern base

b. Pembangkitan FP-Tree

c. Pencarian frequent itemset (Larasati, Nasrun \& Ahmad dalam Bunda, 2020).

Menurut Hermawati (dalam Nurdin \& Astika, 2015) berikut tahapan proses penggunaan data mining yang merupakan bagian dari proses KDD:

a. Mengetahui dan menggali pengetahuan awal dan sasaran pengguna

b. Membuat target data-set, seperti pemelihan data

c. Pembersihan dan transformasi, seperti outliers, dan missing value

d. Algoritme data mining, seperti asosiasi, klasifikasi, klasterisasi, dan lain-lain

e. Evaluasi pola, melihat sesuatu yang baru dan menarik yang dapat dilakukan iterasi jika diperlukan.

\subsection{Algoritme FP-Growth}

Menurut Simamora (2004) yang dikutip oleh Saodah \& Malia (2017) perilaku konsumen dipengaruhi oleh faktor eksternal dan internal dalam 
diri manusia. Faktor eksternal yang utama yaitu faktor kebudayaan dan sosial, faktor internal yang utama yaitu faktor pribadi dan psikologis.

\subsection{Skala Likert}

Skala Likert merupakan skala untuk mengukur persepsi, sikap atau pendapat seseorang atau kelompok dari sebuah peristiwa (Pranatawijaya, Widiatry, Pirskila, \& Putra, 2019).

\section{Metodologi}

\subsection{Studi Literatur}

Studi Literatur dilakukan untuk mengumpulkan informasi yang dibutuhkan pada penelitian ini. Informasi tersebut diperoleh dengan mempelajari dan membaca literatur-literatur yang ada hubungannya dengan permasalahan penelitian ini yang menjadi identifikasi masalah obyek penelitian seperti jurnal, skripsi, publikasi maupun buku yang terkait dengan data mining khususnya algoritme FP-Growth.

\subsection{Pengumpulan Data}

Pengumpulan data dilakukan untuk memperoleh informasi yang dibutuhkan agar tercapai tujuan penelitian yang sesuai. Pada penelitian ini menggunakan jenis data primer dan data sekunder. Data primer adalah data yang diperoleh dari wawancara, sedangkan data sekunder diperoleh dari data transaksi yang dicatat secara manual saat pembeli dan penjual melakukan transaksi disalah satu pedagang sayur perumahan Cibarusah Indah.

\subsection{Knowledge Discovery in Database}

Pada penelitian ini menggunakan metode knowledge discovery in database (KDD) yang dirancang oleh Fayyad et al. (1996) dikutip oleh Tamaela, Sediyono \& Setiawan (2018) yang memiliki tahap yaitu:

\section{a. Data Selection}

Data yang digunakan yaitu data ketika pembeli dan penjual bertransaksi. Data yang diperoleh yaitu 250 data transaksi.

\section{b. Pre-processing}

Pre-processing

dilakukan untuk membersihkan data dengan cara memeriksa data yang inkonsisten. Peneliti hanya membutuhkan data minimal 2 item pada setiap transaksi karena penelitian ini mengenai analisa tentang peletakan barang yang saling berkaitan. Data berjumlah menjadi 215 data setelah dilakukannya preprocessing. Data yang digunakan untuk pembahasan pada penelitian ini yaitu 15 transaksi sebagai data sample.

Tabel 1. Data Sample

\begin{tabular}{|c|c|}
\hline Transaksi & Item yang dibeli \\
\hline T001 & Tomat, Cabai merah, Kemiri \\
\hline T002 & $\begin{array}{l}\text { Oncom, Kacang panjang, Jahe, Daun } \\
\text { bawang, Pete }\end{array}$ \\
\hline T003 & $\begin{array}{l}\text { Daun bawang, Seledri, Oncom, Emping, } \\
\text { Kelapa, Sawi hijau, Bakso jeruk, Pisang }\end{array}$ \\
\hline T004 & Sayur sop, Kembang kol, Daun bawang \\
\hline T005 & Jagung, Bayam, Tempe, Masako \\
\hline T006 & Oyong, Cabai merah, Bawang merah \\
\hline T007 & $\begin{array}{l}\text { Jagung, Leunca, Bayam, Oyong, Kelapa, } \\
\text { Bawang merah } 1 / 4 \mathrm{~kg} \text {, Daun bawang, Ikan } \\
\text { tongkol }\end{array}$ \\
\hline T008 & Bawang merah, Labu siam \\
\hline T009 & Oncom, Genjer, Leunca \\
\hline T010 & $\begin{array}{l}\text { Sayur asem, Jagung, Udang rebon, Cabai } \\
\text { merah, Bakso manggis }\end{array}$ \\
\hline T011 & $\begin{array}{l}\text { Lontong, Cabai merah, Pete, Tomat, Cabai } \\
\text { hijau, Ikan teri, Kol }\end{array}$ \\
\hline T012 & $\begin{array}{l}\text { Ikan tongkol, Kemangi, Bumbu rempah, } \\
\text { Terong, Jamur, Daun salam }\end{array}$ \\
\hline T013 & $\begin{array}{l}\text { Bayam, Kangkung, Tomat, Ikan asin, } \\
\text { Kerupuk, Sayur sop }\end{array}$ \\
\hline T014 & Pete, Kangkung, Ikan teri \\
\hline T015 & Udang rebon, Toge, Kara \\
\hline
\end{tabular}

\section{c. Transformation}

Peneliti menggunakan bahasa pemrograman python sehingga pada tahap transformation ini perlu mengubah data agar dapat dibaca pada pemrograman python. Data transaksi diubah kedalam bentuk data tabular. Nama item dari dataset diubah menjadi kode item " 1 " dan " 0 ". " 1 " memiliki arti bahwa konsumen membeli item tersebut pada transaksi dan " 0 " memiliki arti bahwa konsumen tidak membeli item tersebut pada transaksi.

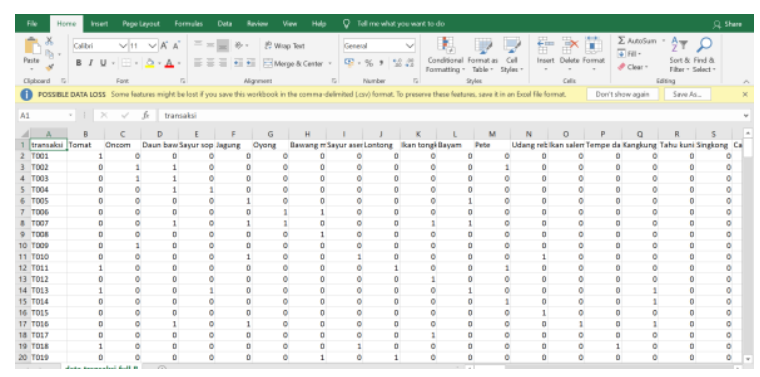

Gambar 1. Data Sample Bentuk Data Tabular

\section{d. Data Mining}

Peneliti menerapkan data mining aturan asosiasi dengan menggunakan algoritme FP-Growth dalam menganalisis data penjualan salah satu 
pedagang sayur agar mendapatkan pola asosiasi yang akan digunakan untuk menentukan peletakan barang di pedagang sayur tersebut. Terdapat beberapa proses dalam tahapan data mining, yaitu:

1. Mempersiapkan dataset

2. Mencari Frequent Itemset

Setelah melakukan pencarian frequent itemset, berikutnya diurutkan berdasarkan frequent itemset terbesar. Peneliti menggunakan minimum support $10 \%$ sehingga diperoleh minimum support count-nya adalah $(10 \% * 15)$ $=1,5$. Tabel 2 merupakan frequent itemset yang memenuhi syarat.

Tabel 2. Itemset yang Memenuhi Syarat

\begin{tabular}{|c|c|c|c|}
\hline No & $\begin{array}{c}\text { Kode } \\
\text { Item }\end{array}$ & Itemset & Frekuensi \\
\hline 1 & C & Cabai merah & 4 \\
\hline 2 & D & Daun bawang & 4 \\
\hline 3 & T & Tomat & 3 \\
\hline 4 & ON & Oncom & 3 \\
\hline 5 & P & Pete & 3 \\
\hline 6 & J & Jagung & 3 \\
\hline 7 & B & Bayam & 3 \\
\hline 8 & K & Kelapa & 2 \\
\hline 9 & OY & Oyong & 2 \\
\hline 10 & BM & Bawang merah & 2 \\
\hline 11 & L & Leunca & 2 \\
\hline 12 & ITO & Ikan tongkol & 2 \\
\hline 13 & U & Udang rebon & 2 \\
\hline 14 & ITE & Ikan teri & 2 \\
\hline 15 & KA & Kangkung & 2 \\
\hline 16 & S & Sayur sop & 2 \\
\hline
\end{tabular}

Tabel 3. Transaksi untuk Pembuatan FP-Tree

\begin{tabular}{|c|c|}
\hline Transaksi & Item yang dibeli \\
\hline T001 & Tomat, Cabai merah \\
\hline T002 & Oncom, Daun bawang, Pete \\
\hline T003 & Daun bawang, Oncom, Kelapa \\
\hline T004 & Daun bawang, Sayur sop \\
\hline T005 & Jagung, Bayam \\
\hline T006 & Cabai merah, Oyong, Bawang merah \\
\hline T007 & $\begin{array}{c}\text { Jagung, Bayam, Daun bawang, Leunca, } \\
\text { Oyong, Ikan tongkol, Kelapa }\end{array}$ \\
\hline T008 & Bawang merah \\
\hline T009 & Oncom, Leunca \\
\hline T010 & Jagung, Cabai merah, Udang rebon \\
\hline T011 & Cabai merah, Pete, Tomat, Ikan teri \\
\hline T012 & Ikan tongkol \\
\hline T013 & Bayam, Tomat, Kangkung, Sayur sop \\
\hline T014 & Pete, Kangkung, Ikan teri \\
\hline T015 & Udang rebon \\
\hline
\end{tabular}

3. Pembuatan FP-Tree

Pada tahap ini merupakan tahap pembangunan FP-Tree berdasarkan tabel 3.

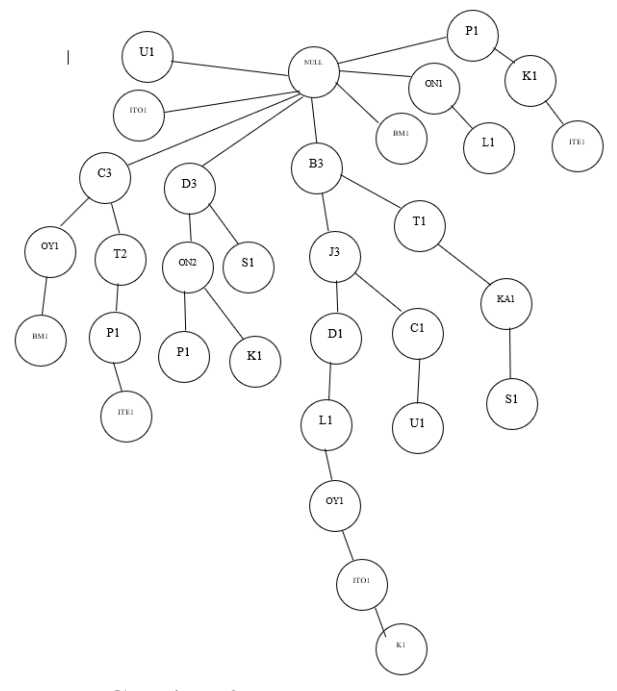

Gambar 2. FP-Tree

4. Pembangkitan Conditional Pattern Base Tabel 4 peneliti melakukan pembangkitan conditional pattern base dengan melihat gambar 2.

Tabel 4. Pembangkitan Conditional Pattern Base

\begin{tabular}{|c|c|}
\hline Suffix & Conditional Pattern Base \\
\hline BM & $\{\mathrm{C}, \mathrm{OY}: 1\}$ \\
\hline ITE & $\{\mathrm{C}, \mathrm{P}, \mathrm{T}: 1\},\{\mathrm{P}, \mathrm{K}: 1\}$ \\
\hline P & $\{\mathrm{ON}, \mathrm{D}: 1\},\{\mathrm{KA}, \mathrm{ITE}: 1\},\{\mathrm{C}, \mathrm{T}, \mathrm{ITE}: 1\}$ \\
\hline K & $\{\mathrm{D}, \mathrm{ON}: 1\},\{\mathrm{J}, \mathrm{B}, \mathrm{D}, \mathrm{L}, \mathrm{OY}, \mathrm{ITO}: 1\}$ \\
\hline S & $\{\mathrm{D}: 1\},\{\mathrm{B}, \mathrm{T}, \mathrm{KA}: 1\}$ \\
\hline $\mathrm{U}$ & $\{\mathrm{J}, \mathrm{C}: 1\}$ \\
\hline L & $\{\mathrm{ON}: 1\},\{\mathrm{J}, \mathrm{B}, \mathrm{D}, \mathrm{OY}, \mathrm{K}, \mathrm{ITO}: 1\}$ \\
\hline
\end{tabular}

5. Pembangkitan Conditional FP-Tree

Tabel 5 merupakan pembangkitan conditional FP-Tree dari tabel 4.

Tabel 5. Conditional FP-Tree

\begin{tabular}{|c|c|}
\hline Suffix & Conditional FP-Tree \\
\hline BM & $\{\mathrm{C}, \mathrm{OY}: 1\}$ \\
\hline ITE & $\{\mathrm{C}, \mathrm{T}, \mathrm{K}: 1\},\{\mathrm{P}: 2\}$ \\
\hline P & $\{\mathrm{ON}, \mathrm{D}, \mathrm{KA}, \mathrm{C}, \mathrm{T}: 1\},\{\mathrm{ITE}: 2\}$ \\
\hline K & $\{\mathrm{D}: 2\},\{\mathrm{ON}, \mathrm{J}, \mathrm{B}, \mathrm{L}, \mathrm{OY}, \mathrm{ITO}: 1\}$ \\
\hline S & $\{\mathrm{J}, \mathrm{KA}: 1\}$ \\
\hline $\mathrm{U}$ & $\{\mathrm{J}, \mathrm{B}, \mathrm{D}, \mathrm{K}, \mathrm{ON}, \mathrm{OY}, \mathrm{ITO}: 1\}$ \\
\hline L &
\end{tabular}

6. Menentukan Frekuensi 2 Itemset

Tabel 6 merupakan tabel untuk menentukan frekuensi 2 itemset yang ditentukan dari tabel 5.

Tabel 6. Frekuensi 2 Itemset

\begin{tabular}{|c|c|}
\hline Suffix & Frekuensi Itemset \\
\hline BM & $\{\mathrm{BM}, \mathrm{C}: 1\},\{\mathrm{BM}, \mathrm{OY}: 1\}$ \\
\hline ITE & $\{\mathrm{ITE}, \mathrm{C}: 1\},\{\mathrm{ITE}, \mathrm{T}: 1\},\{\mathrm{ITE}, \mathrm{K}: 1\}$, \\
& $\{\mathrm{ITE}, \mathrm{P}: 2\}$ \\
\hline $\mathrm{P}$ & $\begin{array}{c}\{\mathrm{P}, \mathrm{ON}: 1\},\{\mathrm{P}, \mathrm{D}: 1\},\{\mathrm{P}, \mathrm{KA}: 1\},\{\mathrm{P}, \mathrm{C}: 1\}, \\
\{\mathrm{P}, \mathrm{T}: 1\},\{\mathrm{P}, \mathrm{ITE}: 2\}\end{array}$ \\
\hline $\mathrm{K}$ & $\begin{array}{c}\{\mathrm{K}, \mathrm{D}: 2\},\{\mathrm{K}, \mathrm{ON}: 1\},\{\mathrm{K}, \mathrm{J}: 1\},\{\mathrm{K}, \mathrm{B}: 1\}, \\
\{\mathrm{K}, \mathrm{L}: 1\},\{\mathrm{K}, \mathrm{OY}: 1\},\{\mathrm{K}, \mathrm{ITO}: 1\}\end{array}$ \\
\hline $\mathrm{S}$ & $\{\mathrm{S}, \mathrm{D}: 1\},\{\mathrm{S}, \mathrm{B}: 1\},\{\mathrm{S}, \mathrm{T}: 1\},\{\mathrm{S}, \mathrm{KA}: 1\}$ \\
\hline $\mathrm{U}$ & $\{\mathrm{U}, \mathrm{J}: 1\},\{\mathrm{U}, \mathrm{C}: 1\}$ \\
\hline $\mathrm{L}$ & $\begin{array}{c}\{\mathrm{L}, \mathrm{J}: 1\},\{\mathrm{L}, \mathrm{B}: 1\},\{\mathrm{L}, \mathrm{D}: 1\},\{\mathrm{L}, \mathrm{ON}: 1\}, \\
\text { LL,OY:1\}, } 1 \mathrm{~L}, \mathrm{ITO}: 1\}\{\mathrm{L}, \mathrm{K}: 1\}\end{array}$ \\
\hline
\end{tabular}


7. Hasil Association Rules

Tabel 7 merupakan hasil association rules yang memenuhi syarat nilai minimum support $10 \%$ dan minimum confidence $90 \%$.

Tabel 7. Hasil Association Rules

\begin{tabular}{|c|c|c|}
\hline Item & Support & Confidence \\
\hline If ITE, Then $\mathrm{P}$ & $2 / 15=0.13$ & $2 / 2=1$ \\
\hline If $\mathrm{K}$, Then $\mathrm{D}$ & $2 / / 15=0.13$ & $2 / 2=1$ \\
\hline
\end{tabular}

\section{e. Evaluation}

Peneliti menyamakan hasil manual dengan program python. Jika hasilnya sama maka dapat dilakukan menggunakan data transaksi seluruhnya.

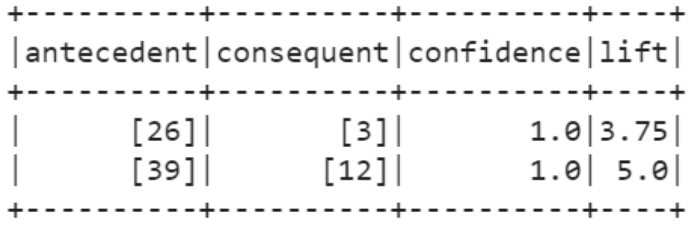

Gambar 3. Hasil Perhitungan Menggunakan Python

Keterangan [26] merupakan nama barang yaitu kelapa, [3] yaitu daun bawang, [12] yaitu pete, dan [39] yaitu ikan teri. Dari gambar 3 dapat dijelaskan bahwa kelapa dapat diletakan berdekatan dengan daun bawang dengan nilai confidence 1 dan ikan teri dapat diletakan berdekatan dengan pete dengan nilai confidence 1 .

\section{Kesimpulan dan Saran}

\subsection{Kesimpulan}

Setelah dilakukan analisis menggunakan data sample. Selanjutnya peneliti melakukan analisis menggunakan data transaksi keseluruhan dengan jumlah 215 transaksi dengan nilai minimum support $1 \%$ dan minimum confidence $90 \%$ dapat menghasilkan 41 rules.

\begin{tabular}{|c|c|c|c|}
\hline \multicolumn{2}{|c|}{ antecedent $\mid$ consequent $\mid$} & confidence | & lift \\
\hline$[5,92,7]$ & [36] & $1 . \theta$ & $|9.772727272727273|$ \\
\hline$[36,92,33] \mid$ & [7] & 1.0 & 5.375 \\
\hline$[32,1,3] \mid$ & [61] & $1.0 \mid$ & 21.5 \\
\hline$[74,92] \mid$ & [3] & 1.0 & $|4.886363636363637|$ \\
\hline$[32,74] \mid$ & [3] & 1.0 & | 4.886363636363637| \\
\hline$[5,11,92]$ & [33] & $1.0 \mid$ & | 4.886363636363637| \\
\hline$[74,23] \mid$ & [3] & 1.0 & | 4.886363636363637| \\
\hline$[36,7,33]$ & [92] & 1.0 & | 5.512820512820513| \\
\hline$[36,5,7] \mid$ & [92] & $1.0 \mid$ & | 5.512820512820513| \\
\hline$[40,12,21] \mid$ & [18] & 1.0 & | $23.88888888888889 \mid$ \\
\hline$[18,40,12]$ & [21] & $1.0 \mid 5$ & | $5.8108108108108105 \mid$ \\
\hline$[37,74,92] \mid$ & [3] & $1 . \theta$ & $|4.886363636363637|$ \\
\hline [74] & [3] & $0.9473684210526315 \mid$ & |4.6291866028708135| \\
\hline$[18,12,21]$ & [40] & $1 . \theta \mid$ & $|11.944444444444445|$ \\
\hline$[38,20] \mid$ & [7] & 1.0 & 5.375 \\
\hline$[11,21]$ & [5] & 1.0 & | 8.958333333333334| \\
\hline$[4 \theta, 1] \mid$ & [21] & $1.0 \mid 5$ & | $5.8108108108108105 \mid$ \\
\hline$[61,32,1] \mid$ & [3] & 1.0 & $|4.886363636363637|$ \\
\hline$[20,7,33] \mid$ & [92] & 1.0 & | 5.512820512820513| \\
\hline$[36,11] \mid$ & [33] & $1.0 \mid$ & | 4.886363636363637| \\
\hline
\end{tabular}

Gambar 4. Hasil 215 Transaksi

Association Rules dapat diterapkan dipedagang sayur karena setelah didapatkan hasil analisis, maka pedagang sayur dapat meletakan sayuran sesuai rules yang didapatkan. Seperti jagung, penyedap makanan dan bawang merah dapat diletakan berdekatan cabai campur. Peneliti melakukan wawancara kepada beberapa pembeli, setelah dilakukan wawancara ibu-ibu mengisi kuisioner yang telah disediakan. Hasil dari kuisioner tersebut dihitung dengan menggunakan skala likert dengan pertanyaan "Apakah lebih mudah menemukan sayuran setelah dianalisis dibandingkan sebelumnya?" dari total 5 responden didapatkan hasil indeksnya yaitu $84 \%$, maka dapat disimpulkan bahwa responden sangat setuju.

\subsection{Saran}

Berdasarkan hasil penelitian, maka diberikan saran-saran untuk menjadi referensi penelitian selanjutnya yaitu:

a. Jika dilakukan pengembangan terhadap penelitian ini, sebaiknya jumlah transaksi lebih banyak dari data yang telah diambil

b. Pada penelitian ini penulis menggunakan bahasa pemrograman python. Jika dilakukan pengembangan terhadap penelitian ini, sebaiknya menggunakan bahasa pemrograman yang lain seperti $\mathrm{R}$.

\section{Daftar Pustaka:}

Sapari, M. (2016): Analisis Pendapatan Pedagang Sayur Keliling Di Desa Purwodadi Kecamatan Kuala Pesisir Kabupaten Nagan Raya. (Skripsi). Universitas Teuku Umar, Aceh Barat.

Khair, H. (2016): Dampat Atribut Toko Terhadap Keputusan Pembelian Pada Indomaret Dept Store di Medan. Jurnal Ilmiah dan Bisnis, Vol. 2(1), pp. 78-95.

Parhusip, F. (2019): Pemanfaatan data mining penempatan buku perpustakaan menggunakan metode association rule (study kasus: sma negeri 1 sidamanik). Jurnal Manajemen Informatika \& Komputerisasi Akuntansi, Vol. 3(1), pp. 61-65.

Afdal, M., \& Rosadi, M. (2019): Penerapan association rule mining untuk analisis penempatan tata letak buku di perpustakaan menggunakan algoritma apriori. Jurnal Ilmiah Rekayasa dan Manajemen Sistem Informasi, Vol. 5(1), pp. 99-108.

Sikumbang, E. D. (2018): Penerapan data mining penjualan sepatu menggunakan metode algoritma apriori. Jurnal Teknik Komputer, Vol. 4(1), pp. 156-161.

Junaidi, A. (2019): Implementasi algoritma apriori dan fp-growth untuk menentukan persediaan barang. Jurnal SISFOKOM, Vol. 8(1), pp. 6167.

Sholikin. (2019): Algoritma fp-growth dalam teknik market basket analysis sparepart komputer pada jasa servis komputer (studi kasus: cv. Karya 
computer center). Jurnal Pelita Informatika, Vol. 8(4), pp. 597-602.

Bunda, Y. P. (2020). Algoritma fp-growth untuk menganalisa pola pembelian oleh-oleh (studi kasus dipusat oleh-oleh ummi aufa hakim). Riau Journal of Computer Science, Vol. 6(1), pp. 3444.

Saodah, D. S., \& Malia, R. (2017). Faktor-faktor yang mempengaruhi konsumen dalam pembelian sayuran di pasar tradisional (studi kasus pasar muka cianjur). Journal Agroscience, Vol. 7(1), pp. 178-193.

Tamaela, J., Sediyono, E., \& Setiawan, A. (2018). Implementasi metode association rule untuk menganalisis data twitter tentang badan penyelenggara jaminan sosial dengan algoritma frequent pattern-growth. Jurnal Sistem Informasi Bisnis, Vol. 1, pp. 25-33.

Fajrin, A. A., \& Maulana, A. (2018). Penerapan data mining untuk analisis pola pembelian konsumen dengan algoritma fp-growth pada data transaksi penjualan spare part motor. Jurnal Ilmu Komputer, 5 (1), 27-36.

Hanum, Z., \& Hidayat, S. (2017). Factor-faktor yang mempengaruhi perilaku konsumen dalam keputusan pembelian sepatu merek nike di kota medan. Jurnal Bisnis Administrasi, 6 (1), 37-43.

Lelawati, P. S. (2015). Eksistensi pedagang kecil di kecamatan rumbai pesisir kota pekanbaru. Jurnal Jom Fisip, 2 (2), 1-12.

Merlina, N., \& Rahmawati, F. (2018). Metode data mining terhadap data penjualan sparepart mesin fotocopy menggunakan algoritma apriori. Jurnal Penelitian Ilmu Komputer System Embedded \& Logic, 6 (1), 9-20.

Nurdin, \& Astika, D. (2015). Penerapan data mining untuk menganalisis penjualan barang dengan menggunakan metode apriori pada supermarket sejahtera. Jurnal Techsi, 6 (1), 134-155. 